\title{
PEMBUATAN DEKSTRIN DARI PATI UBI KAYU MENGGUNAKAN KATALIS AMILASE HASIL FRAKSINASI DARI Azospirillum sp. JG3
}

\author{
Zusfahair dan Dian Riana Ningsih \\ Program Studi Kimia Jurusan MIPA Fakultas Sains dan Teknik \\ Universitas Jenderal Soedirman Purwokerto \\ J1. Soeparno 62, Karangwangkal, Purwokerto Jawa Tengah 53123 \\ email: zusfahair@gmail.com
}

\begin{abstract}
ABSTRAK
Amilase merupakan salah satu enzim potensial dalam proses industri. Amilase dapat diperoleh dari bakteri Azopsirillum sp. JG3. Amilase ini dapat dimanfaatkan untuk hidrolisis pati ubi kayu pada pembuatan dekstrin. Dekstrin memiliki peran yang cukup penting dalam industri seperti pembuatan roti, makanan bayi dan bahan penyalut lapis tipis tablet. Penelitian ini bertujuan untuk mengetahui karakterisasi biokimiawi amilase hasil fraksinasi dari Azospirillum sp. JG3 serta potensinya dalam pembuatan dekstrin.

Tahap penelitian ini dimulai dengan memproduksi enzim yang dilakukan dengan cara menumbuhkan inokulum ke dalam medium produksi selama 30 jam kemudian diekstraksi dengan sentrifugasi sehingga diperoleh ekstrak kasar. Ekstrak kasar amilase kemudian difraksinasi secara bertahap $(15 \%, 30 \%, 45 \%$ dan $60 \%)$ dengan menggunakan ammonium sulfat dan didialisis. Fraksi yang diperoleh diukur aktivitas, volume dan kadar proteinnya. Fraksi dengan aktivitas spesifik tertinggi dikarakterisasi dan digunakan untuk membuat dekstrin dari pati ubi kayu. Dekstrin pati ubi kayu yang diperoleh dikarakterisasi berupa rendemen, kadar air, kadar abu dan dextrose equivalen.

Hasil penelitian menunjukkan bahwa fraksi hasil dialisis 45\% (FHD 45\%) menghasilkan aktivitas dan aktivitas spesifik tertinggi berturut-turut sebesar 11,659 U/mL dan $7,319 \mathrm{U} / \mathrm{mg}$. Aktivitas amilase optimum pada suhu $30^{\circ} \mathrm{C}, \mathrm{pH} 7$ dan konsentrasi substrat $4 \%$. Dekstrin yang diperoleh memiliki rendemen 95,14, kadar air 3,411\%, kadar abu $0,209 \%$ dan dextrose equivalen 13,4 .
\end{abstract}

Kata kunci : amilase, Azospirillum sp. JG3, dekstrin

\section{THE MAKING OF DEXTRIN OF CASSAVA STARCH USING AMYLASE OF FRACTINATION CATALYST FROM Azospirillum sp. JG3}

\begin{abstract}
Amylase is one of potential enzyme in industrial processes. Amylase can be obtained from bacteria Azopsirillum sp. JG3. Amylase can be used to hydrolysis starch of cassava in making of dextrin. Dextrin have an important role in industries such as making bread, baby food and a thin layer coating of tablets. This research aims to determine biochemical characterization of amylase fractionation of Azospirillum sp. JG3 and its potential in making dextrin.

This research began with producing an enzyme that was done by growing the inoculums into the production medium until 30 hours and then been extracted with centrifuge to obtain crude extract. The crude extract of amylase was fractionated continually $(15 \%, 30 \%, 45 \%$ and $60 \%)$ by using ammonium sulfate and were dialyzed.
\end{abstract}


Fractions of amylase that was obtained had been measured its activity, volume and protein content. Fractions with highest specific activity were characterized and used to make dextrin from cassava starch. Cassava starch dextrin that was obtained had been characterized in the form of rendement, water content, ash content and dextrose equivalent.

The results showed that fraction of dialysis $45 \%$ yield the highest activity and specific activity were $11.659 \mathrm{U} / \mathrm{mL}$ and $7.319 \mathrm{U} / \mathrm{mg}$. Amylase activity optimum at $30^{\circ} \mathrm{C}, \mathrm{pH} 7$ and substrate concentration at $4 \%$. The rendement of dextrin was $95.14 \%$, the water content was $3.411 \%$, ash content was $0.209 \%$ and the dextrose equivalent at 13.4 .

Keywords: Amylase, Azospirillum sp. JG3, dextrin

\section{PENDAHULUAN}

Dekstrin memiliki banyak manfaat dalam industri pangan dan farmasi diantaranya yaitu pada produksi makanan beku, roti, bahan minuman prebiotik dan bahan penyalut lapis tipis (film coating) tablet. Dekstrin dimanfaatkan sebagai pengganti gula dan untuk mempertahankan produk tetap beku. Kebutuhan dekstrin di bidang industri ini semakin meningkat, sedangkan sebagian besar dekstrin yang dibutuhkan masih impor. Hal ini menyebabkan diperlukan adanya produksi dekstrin yang dapat memenuhi kebutuhan industri tersebut terutama yang berasal dari sumber lokal seperti ubi kayu (Manihot esculenta Crantz).

Ubi kayu merupakan tanaman yang mudah beradaptasi di daerah tropis maupun subtropis dan mudah diperoleh dengan harga murah. Ubi kayu memiliki kandungan pati yang cukup tinggi yaitu mencapai $34,70 \%$ dalam 100 gram bahan (Rukmana dan Yuniarsih, 2001) sehingga tanaman ini sangat cocok dimanfaatkan sebagai sumber pati dalam pembuatan dekstrin. Pemanfaatan ubi kayu sebagai sumber pati bagi dekstrin selain untuk memenuhi kebutuhan dekstrin di bidang industri, juga dapat meningkatkan nilai ekonomi ubi kayu (Chafid dan Kusumawardani, 2010). Pati ubi kayu akan lebih cepat menjadi dekstrin melalui reaksi hidrolisis parsial dengan adanya bantuan enzim amilase. Dekstrin yang dihasilkan pada reaksi hidrolisis parsial dapat diuji secara kualitatif dengan uji iodin sehingga dihasilkan warna merah kecoklatan, sedangkan pati dengan uji iodin menghasilkan warna biru

Enzim amilase yang digunakan dalam proses hidrolisis pembuatan dekstrin dapat diperoleh dari mikroorganisme. Penggunaan enzim dari mikroorganisme memiliki beberapa kelebihan diantaranya adalah isolasi lebih mudah, lebih sederhana dibandingkan enzim yang berasal dari tumbuhan maupun hewan dan dapat dikendalikan dengan baik pada proses pembuatannya. Hasil uji enzimatik yang dilakukan oleh Oedjijono dkk. (2007) terhadap isolat bakteri Azospirillum sp. JG3 menunjukkan bahwa bakteri ini memiliki kemampuan amilolitik, selulotik, proteolitik dan lipolitik. Berdasarkan kemampuan amilolitik yang dimiliki diharapkan isolat bakteri Azospirillum sp. JG3 dapat menghasilkan enzim amilase yang digunakan sebagai katalis dalam hidrolisis pati ubi kayu. Tujuan penelitian adalah mengetahui karakteristik biokimiawi amilase hasil fraksinasi dari bakteri Azospirillum sp. JG3 dan potensinya dalam pembuatan dekstrin.

\section{METODE PENELITIAN}

\section{Alat dan Bahan}

Alat-alat yang digunakan dalam penelitian adalah alat gelas, termometer, jarum ose $\mathrm{pH}$ meter "Hanna instrument", 
eppendorf, pipet mikro otomatis merk Wheaton Soccorex, sentrifuge "Heraeus", shaker bath merk "Memmert", water bath merk "Memmert", incubator merk "Venticell", autoklaf, timbangan analitik, oven merk "Memmert", hot plate stirrer, magnetic stirer kompor listrik merk "Maspion", pembakar spirtus, Spektrofotometer UV-Vis merk "Shimidzu UV-1601", dan mortar.

Bahan-bahan yang digunakan dalam penelitian ini adalah isolat bakteri Azospirillum sp. JG3, medium Nutrien Agar, medium inokulum (yeast ekstrak, pepton, amilum) medium produksi, ammonium sulfat, $\mathrm{NaCl} 1 \%$, EDTA dalam $1 \%$ (b/v) $\mathrm{Na}_{2} \mathrm{CO}_{3}, \mathrm{NaCl} 0,85 \%$, amilum 1\%, Na-wolframat $10 \%$, asam sulfat $2 / 3 \mathrm{~N}$, glukosa, pereaksi Cu-tartrat alkalis, arsenomolibdat, akuades, ubi kayu segar diambil dari desa Padamara Purbalingga, etanol 95\%, Iodin, Larutan Fehling A dan B, label, kantong selofan, buffer natrium asetat $\mathrm{pH} 5$, buffer $\mathrm{Na}$ fosfat $\mathrm{pH}$ 6-7, buffer Tris- $\mathrm{HCl} \mathrm{pH}$ 8-9 dan $\mathrm{Ba}(\mathrm{OH})_{2} .8 \mathrm{H}_{2} \mathrm{O} 2 \%$, pereaksi A $(2 \%$ $\mathrm{Na}_{2} \mathrm{CO}_{3}$ dalam $0,1 \mathrm{M} \mathrm{NaOH}$ ), pereaksi B $(0,5 \% \quad \mathrm{CuSO} 4.5 \mathrm{H} 2 \mathrm{O}$ dalam $1 \% \mathrm{Na}-\mathrm{K}$ tartrat, pereaksi C (campuran $50 \mathrm{ml}$ pereaksi A dan $1 \mathrm{ml}$ pereaksi B), pereaksi E (larutan $1 \mathrm{~N}$ pereaksi Folin Ciocalteu), larutan standar protein BSA (Bovine serum albumin).

\section{Prosedur Penelitian}

\section{Produksi amilase}

Isolat bakteri yang sudah diremajakan diinokulasi dengan cara memindahkan satu ose biakan bakteri ke dalam medium inokulum diinkubasi pada suhu ruang selama 12 jam. Sebanyak $10 \%$ inokulum pada fase eksponensialnya diinokulasikan ke medium produksi dan diinkubasi selama 30 jam pada suhu ruang dalam shaker incubator.

\section{Ekstraksi (Shaw et al., 1995)}

Amilase yang telah diproduksi kemudian dipanen dengan cara mensentrifus medium produksi pada kecepatan $10.000 \mathrm{rpm}$ selama 10 menit pada keadaan dingin $\left(4^{\circ} \mathrm{C}\right)$. Supernatan yang merupakan ekstrak kasar enzim amilase ditampung dan pelet dibuang.

\section{Fraksinasi amilase (Soebardjo dan Soedigdo, 1992)}

Ekstrak kasar amilase difraksinasi menggunakan garam ammonium sulfat dengan konsentrasi 15\%, 30\%, 45\% dan $60 \%$. Garam ammonium sulfat $(15 \%)$ dilarutkan dalam ekstrak kasar amilase kemudian diaduk menggunakan magnetic stirer sampai terbentuk endapan. Ekstrak kasar amilase kemudian disentrifus pada kecepatan $10000 \mathrm{rpm}$ selama 10 menit. Endapan yang diperoleh dilarutkan dalam $25 \mathrm{~mL} \mathrm{NaCl} 1 \%$ dan disimpan pada suhu $4^{\circ} \mathrm{C}$ sebagai fraksi endapan $15 \%$ (F15). Supernatannya ditambah garam ammonium sulfat hingga konsentrasi akhir $30 \%$, selanjutnya dilakukan hal yang sama seperti F15, demikian pula dengan fraksi $45 \%$ dan $60 \%$ sehingga diperoleh F30, F45, dan F60.

\section{Dialisis (Subardjo dan Soedigdo, 1992)}

Semua fraksi yang diperoleh didialisis menggunakan kantong selofan untuk membebaskan molekul garamnya. Kantong selofan sebelumnya direndam dengan asam asetat $1 \%$ selama 1 jam lalu dibilas dengan akuades selama 15 menit, setelah itu direndam kembali dengan $0,001 \mathrm{M}$ EDTA dalam $1 \%$ (b/v) $\mathrm{Na}_{2} \mathrm{CO}_{3}$ dan direndam dalam akuades $75^{\circ} \mathrm{C}$ hingga dingin. Fraksi-fraksi endapan tersebut dimasukan ke dalam kantong selofan kemudian bagian atas dan bagian bawah kantong selofan diikat. Dialisis dilakukan pada suhu $4^{\circ} \mathrm{C}$ sambil diaduk dengan menggunakan magnetic stirer. Dialisis dilakukan selama 15 jam dengan pergantian dialisat setiap 30 menit. Setiap dialisat yang dikeluarkan diuji dengan larutan $\mathrm{Ba}(\mathrm{OH})_{2} .8 \mathrm{H}_{2} \mathrm{O} \quad 2 \%$ untuk mengetahui apakah masih terdapat garam. Dialisis dihentikan bila dialisat 
sudah tidak mengandung garam yang ditandai dengan tidak terbentuk endapan warna putih. Fraksi hasil dialisis dinamakan FHD15, FHD30, FHD45 dan FHD60 (Fraksi 15\%, 30\%, 45\% dan $60 \%$ ). Hasil dialisis diukur volume, aktivitas, karakteristik dan potensinya untuk pembuatan dekstrin.

\section{Pengukuran aktivitas amilase (Metode Nelson-Somogy dalam Alexander dan Joan, 1993)}

Pengukuran aktivitas amilase dilakukan dengan prosedur sebagai berikut: ke dalam tabung reaksi kontrol dimasukan $0,5 \mathrm{~mL}$ larutan enzim dan 0,5

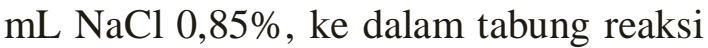
sampel dimasukan $5 \mathrm{~mL}$ substrat amilum $1 \%$, pada tabung kontrol ditambahkan 1 $\mathrm{mL}$ larutan Na-wolframat $10 \%$ dan $1 \mathrm{~mL}$ asam sulfat $2 / 3 \quad \mathrm{~N}$. Kedua tabung diinkubasi pada suhu $37^{\circ} \mathrm{C}$ asal selama 5 menit. Tabung reaksi sampel ditambah $0,5 \mathrm{~mL}$ larutan enzim dan $0,5 \mathrm{ml} \mathrm{NaCl}$ $0,85 \%$ kemudian inkubasi dilanjutkan selama 30 menit. Aktivitas enzim dihentikan dengan menambahkan ke dalam tabung sampel $1 \mathrm{~mL} \mathrm{Na-wolframat}$ $10 \%$ dan $1 \mathrm{~mL}$ asam sulfat 2/3 N. Tabung kontrol ditambahkan $5 \mathrm{~mL}$ substrat amilum $1 \%$ dan dicampur baik-baik.

Aktivitas amilase ditentukan dengan cara mengukur terbentukanya gula pereduksi menurut metode Somogy-Nelson yaitu ke dalam tabung dimasukan masing-masing $0,2 \mathrm{~mL}$ larutan sampel, 0,2 larutan kontrol dan $0,2 \mathrm{~mL}$ larutan glukosa standar 0,$1 ; 0,2$; 0,$3 ; 0,4 ; 0,5 \mathrm{mg} / \mathrm{mL}$. Masing-masing larutan ditambahkan $0,2 \mathrm{~mL}$ reagen $\mathrm{Cu}-$ tartrat alkalis, kemudian diaduk. Tabung reaksi ditutup dan dipanaskan dalam penangas air mendidih selama 30 menit, kemudian didinginkan dalam air dan ditambahkan $0,2 \quad \mathrm{~mL}$ pereaksi arsenomolibdat. Campuran dihomogenkan lalu diencerkan dengan menambahkan 7,4 mL akuades. Serapan diukur pada panjang gelombang $660 \mathrm{~nm}$.

\section{Penentuan kadar protein dengan Metode Lowry (Bollag et al., 1996)}

Kadar protein hasil ekstraksi dan fraksinasi ditetapkan untuk menghitung aktivitas spesifik amilase. Serangkaian larutan standar protein BSA (Bovine serum albumin) dengan konsentrasi 0,1 ; 0,$2 ; 0,4 ; 0,6 ; 0,8$ dan $1 \mathrm{mg} / \mathrm{mL}$ dalam buffer Tris- $\mathrm{HCl}$ pH 8 disiapkan dan masing-masing dimasukkan ke dalam tabung reaksi yang berbeda sebanyak 0,5 $\mathrm{mL}$ larutan protein dan larutan enzim, kemudian ditambahkan dengan $5 \mathrm{~mL}$ pereaksi C. Setiap tabung reaksi dibiarkan pada suhu kamar selama 10 menit, kemudian ditambah $0,5 \mathrm{~mL}$ pereaksi E dan dikocok. Larutan pada setiap tabung diukur absorbansinya dengan spektrofotometer visibel pada panjang gelombang $750 \mathrm{~nm}$. Kadar protein yang diperoleh digunakan untuk penentuan aktivitas spesifik.

\section{Penentuan suhu optimum enzim}

Prosedur kerja penetapan suhu optimum enzim sama seperti pada uji aktivitas. Pengujian dilakukan pada $\mathrm{pH}$ optimum yang telah ditentukan sebelumnya dengan variasi suhu inkubasi pada $25^{\circ} \mathrm{C}, 30^{\circ} \mathrm{C}, 35^{\circ} \mathrm{C}, 40^{\circ} \mathrm{C}, 45^{\circ} \mathrm{C}$ dan $50^{\circ} \mathrm{C}$.

\section{Penentuan pH optimum enzim}

Prosedur kerja penetapan $\mathrm{pH}$ optimum enzim sama seperti pada uji aktivitas, tetapi dengan variasi $\mathrm{pH}$ yaitu $5,6,7,8$ dan 9. Buffer $\mathrm{pH}$ yang digunakan adalah bufer natrium asetat $\mathrm{pH}$ 5, bufer Na-fosfat $\mathrm{pH}$ 6-7, bufer Tris- $\mathrm{HCl}$ pH 8-9.

\section{Penentuan konsentrasi substrat optimum \\ Prosedur penentuan substrat} optimum sama seperti uji aktivitas, dilakukan pada $\mathrm{pH}$ dan suhu optimum amilase. Variasi konsentrasi substrat yang digunakan adalah $2 \%, 4 \%, 6 \%, 8 \%$ dan $10 \%$. 


\section{Pembuatan dekstrin dari ubi kayu}

\section{a. Isolasi pati dari ubi kayu}

Sebanyak 625 g ubi kayu segar yang telah dicuci dipotong-potong, kemudian dihaluskan dengan $500 \mathrm{~mL}$ air selama 1 menit $(2 \mathrm{x})$. Ubi yang telah lumat disaring dengan kain muslin, kemudian dimasukkan ke dalam gelas piala $500 \mathrm{~mL}$. Cairan yang keruh dibiarkan mengendap dan kemudian didekantasi. Endapan ditambah $100 \mathrm{~mL}$ air, diendapkan dan didekantasi. Endapan yang diperoleh ditambah dengan $50 \mathrm{~mL}$ akuades sambil diaduk, kemudian disaring dengan corong butcner. Pati yang diperoleh dikeringkan pada suhu kamar, diletakkan di atas kaca arloji yang telah ditetapkan bobotnya dan ditimbang.

\section{b. Pembuatan dekstrin secara enzimatik (Shi, 2000)}

Pati ubi kayu dilarutkan dengan akuades. Larutan pati dimasukkan ke dalam gelas piala di atas water bath berisi air. Gelatinisasi dilakukan selama 3 jam dalam hotplate stirer dengan suhu $95^{\circ} \mathrm{C}$. Suhu diturunkan hingga $30^{\circ} \mathrm{C}$. Enzim amilase ditambahkan dengan perbandingan enzim:substart (1:10) sambil diaduk. Campuran terus diaduk dan diambil untuk dilakukan uji kualitatif dengan menggunakan larutan iodin setiap 60 menit sampai terbentuk warna merah kecoklatan pada jam ke-22. Campuran lalu dipanaskan pada air mendidih untuk menghentikan aktivitas enzim. Dekstrin cair yang diperoleh kemudian dikeringkan, setelah kering dekstrin tersebut dihaluskan dan dianalisis.

\section{Analisis dekstrin}

\section{a. Rendemen}

Rendemen dekstrin yang diperoleh dapat dihitung dengan cara membandingkan antara berat pati yang digunakan dan berat dekstrin yang diperoleh.

Rendemen $=\frac{b}{a} x 100 \%$ $\mathrm{a}=$ berat pati yang digunakan $(\mathrm{g})$

$\mathrm{b}=$ berat dekstrin yang diperoleh $(\mathrm{g})$

\section{b. Kadar air (Sudarmaji, 1984)}

Dekstrin ditimbang sebanyak $2 \mathrm{~g}$, dimasukkan ke dalam cawan porselin yang sebelumnya telah ditimbang dan diketahui beratnya. Cawan porselin beserta dekstrin kemudian dimasukkan ke dalam oven yang diatur suhunya pada $105^{\circ} \mathrm{C}$ selama 3 jam, kemudian didinginkan dalam desikator dan ditimbang massanya.

$$
\text { Kadar Air }=\frac{(a-b)}{a} x 100 \%
$$

Dimana;

$\mathrm{a}=$ berat dekstrin awal $(\mathrm{g})$

$\mathrm{b}=$ berat dekstrin setelah dikeringkan $(\mathrm{g})$

\section{c. Kadar abu (Sudarmadji, 1984)}

Dekstrin ditimbang sebanyak $2 \mathrm{~g}$, dimasukkan ke dalam cawan porselin yang telah diketahui beratnya, kemudian dipijarkan dalam muffle furnace suhu $600^{\circ} \mathrm{C}$ selama 4 jam atau sampai semua deksrin jadi abu. Cawan didinginkan dalam desikator dan ditimbang.

Kadar $\mathrm{Abu}=\frac{a}{b} \times 100 \%$

Dimana;

$\mathrm{a}=$ berat $\mathrm{abu}(\mathrm{g})$

$\mathrm{b}=$ berat kering pada saat awal $(\mathrm{g})$

\section{d. Nilai dexstrose equivalen (Shi, 2000)}

Nilai Dextrose equivalen diawali dengan mencari nilai Fehling factor dengan cara 2,5 gram glukosa dilarutkan dengan akuades sampai $1000 \mathrm{ml}$ lalu diambil $15 \mathrm{~mL}$ dan ditambah larutan Fehling A dan B masing-masing $5 \mathrm{~mL}$. Campuran didihkan kemudian dititrasi dengan larutan glukosa sampai warna coklat kemerahan, kebutuhan titran dicatat lalu Fehling factor dihitung dengan cara:

Kebutuhan titran $(\mathrm{mL}) \mathrm{x}$ berat glukosa $(\mathrm{g})$ 
Nilai Dextrose equivalen ditentukan dengan cara: larutan dekstrin dibuat dengan konsentrasi $1 \mathrm{~g} / 100 \mathrm{~mL}$ dari hasil pembuatan dekstrin sebelumnya dengan basis pati kering, lalu dimasukkan buret. $50 \mathrm{~mL}$ akuades ditambahkan masing-masing $5 \mathrm{~mL}$ larutan Fehling A dan B dan $15 \mathrm{~mL}$ larutan glukosa. Larutan didihkan dan dititrasi dengan larutan pati sampai berwarna coklat kemerahan. Titran yang dibutuhkan dicatat.

\section{HASIL DAN PEMBAHASAN}

Ekstrak kasar amilase yang diperoleh dari bakteri Azospirillum sp. JG3 memiliki umur inokulum 12 jam dan diproduksi secara optimum selama 30 jam (Ningsih dan Zusfahair, 2010). Ekstrak kasar amilase ini selanjutnya difraksinasi menggunakan garam amonium sulfat $\left(\left(\mathrm{NH}_{4}\right)_{2} \mathrm{SO}_{4}\right)$ dan didialisis. Penggunaan garam ammonium sulfat karena mampu mengendapkan protein dengan baik, dapat menstabilkan protein yang diendapkan, tidak beracun dan dapat digunakan pada $\mathrm{pH}$ tinggi (Scopes, 1987). Fraksi enzim dialisis dan ekstrak kasar diuji aktivitas dan kadar proteinnya yang dapat dilihat pada Tabel 1.

Berdasarkan hasil penelitian seperti terlihat pada Tabel 1, menunjukkan bahwa fraksi dengan aktivitas spesifik tertinggi yaitu fraksi hasil dialisis $45 \%$ dengan aktivitas spesifik sebesar 7,319 U/mg. Fraksi ini diduga mempunyai kelarutan yang relatif tinggi, dengan kemurnian 5,577 kali lebih besar dari ekstrak kasarnya. Fraksi-fraksi ammonium sulfat mempunyai kadar protein yang lebih rendah dari ekstrak kasarnya, hal ini karena fraksi ammonium sulfat telah melalui proses pemisahan yang menyebabkan protein non enzim yang tercampur dengan enzim berkurang. Fraksi hasil dialisis $45 \%$ ini selanjutnya ditentukan sifat-sifat biokimiawinya dan digunakan dalam pembuatan dekstrin.

Tabel 1. Data aktivitas spesifik ekstrak kasar dan fraksi hasil dialisis enzim amilase dari Azospirillum sp. JG3

\begin{tabular}{|l|c|c|c|c|}
\hline \multicolumn{1}{|c|}{ Fraksi } & $\begin{array}{c}\text { Aktivitas enzim } \\
(\mathbf{U} / \mathbf{m L})\end{array}$ & $\begin{array}{c}\text { Kadar Protein } \\
(\mathbf{m g} / \mathbf{m L})\end{array}$ & $\begin{array}{c}\text { Aktivitas Spesifik } \\
(\mathbf{U} / \mathbf{m g})\end{array}$ & $\begin{array}{c}\text { Kemurnia } \\
\mathbf{n}\end{array}$ \\
\hline Ekstrak Kasar & 3,445 & 2,625 & 1,312 & 1,000 \\
\hline FHD 15\% & 3,726 & 1,396 & 2,669 & 2,034 \\
\hline FHD 30\% & 3,095 & 0,587 & 5,273 & 4,018 \\
\hline FHD 45\% & $\mathbf{1 1 , 6 5 9}$ & $\mathbf{1 , 5 9 3}$ & $\mathbf{7 , 3 1 9}$ & $\mathbf{5 , 5 7 7}$ \\
\hline FHD 60\% & 0,023 & 0,571 & 0,040 & 0,031 \\
\hline
\end{tabular}

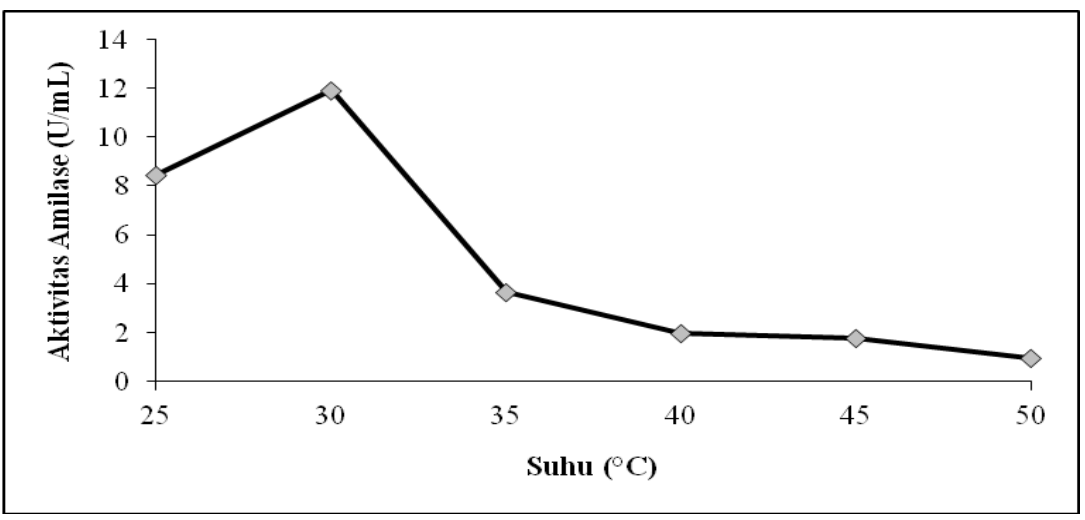

Gambar 1. Kurva pengaruh suhu terhadap aktivitas amilase Azospirillum sp. JG3 


\section{Karakterisasi Enzim Amilase}

\section{Penentuan suhu optimum}

Penentuan suhu optimum fraksi hasil dialisis $45 \%$ dilakukan untuk mendapatkan suhu optimum amilase sehingga diperoleh aktivitas optimum. Hasil yang diperoleh dapat dilihat pada Gambar 1.

Berdasarkan hasil penelitian seperti terlihat pada Gambar 1 dan didukung analisis statistik, diketahui bahwa suhu $30^{\circ} \mathrm{C}$ berbeda nyata dengan suhu lainnya dan mempunyai nilai aktivitas 11,934 U/mL, sehingga dapat disimpulkan suhu optimum amilase FHD 45\% dari Azospirillum sp. JG3 adalah $30^{\circ} \mathrm{C}$. Aktivitas enzim dibawah $30^{\circ} \mathrm{C}$ memiliki aktivitas yang rendah disebabkan oleh rendahnya energi kinetik molekul enzim dan substrat. Aktivitas enzim semakin meningkat dengan kenaikan suhu hingga mencapai optimum, hal ini terjadi karena meningkatnya energi kinetik yang memperbesar peluang terjadinya tumbukan antara enzim dan substrat untuk bereaksi membentuk kompleks enzim-substart sehingga produk yang dihasilkan meningkat. Kenaikan suhu melebihi suhu optimum menyebabkan penurunan aktivitas. Hal ini karena enzim mengalami denaturasi akibat panas yang tinggi. Suhu tinggi akan memecah ikatanikatan sekunder seperti ikatan hidrogen yang mempertahankan enzim pada suhu alaminya, sehingga struktur sekunder dan tersier enzim akan rusak secara parsial diikuti dengan menurunnya aktivitas (Poedjiadi, 1994).

Azospirillum sp. JG3 merupakan bakteri mesofil yang hidup di dalam tanah. Menurut Theil (1999), bakteri mesofil memiliki suhu antara $20-50^{\circ} \mathrm{C}$. Hal ini juga berpengaruh terhadap suhu optimum amilase yang diperoleh berada pada suhu mesofil. Hasil penelitian yang diperoleh berbeda dengan hasil yang diperoleh Azmi (1997) dan Moreira (1999). Azmi (1997) memekatkan enzim amilase dari Aspergillus oryzae dengan ammonium sulfat $80 \%$ dan diperoleh suhu optimum amilase pada $40^{\circ} \mathrm{C}$. Moreira (1999) melaporkan amilase yang diproduksi dari Aspergillus tamarii memilki suhu optimum $55^{\circ} \mathrm{C}$.

\section{Penentuan pH optimum}

Berdasarkan hasil penelitian seperti Gambar 2 dan didukung dengan analisis statistik, menunjukkan bahwa aktivitas enzim pada $\mathrm{pH} 7$ berbeda nyata dengan aktivitas enzim pada $\mathrm{pH}$ yang lain dengan aktivitas tertinggi adalah 11,980 $\mathrm{U} / \mathrm{mL}$. Hal ini menunjukan bahwa $\mathrm{pH}$ optimum amilase Azospirillum sp. JG3 adalah 7. Aktivitas enzim terus meningkat hingga tercapai $\mathrm{pH}$ optimum dan menurun setelah $\mathrm{pH}$ optimum. Perubahan $\mathrm{pH}$ merubah ionisasi rantai samping asam amino pada sisi aktif enzim dan akan berada pada kondisi paling baik ketika pH optimum (Garret dan Grisham, 1999). Enzim yang memiliki struktur tiga dimensi yang tepat dan berada pada konformasi terbaik menyebabkan enzim dapat mengikat dan mengolah substrat dengan kecepatan maksimum sehingga menghasilkan produk secara maksimum (Sadikin, 2002).

Hasil yang diperoleh sesuai dengan pernyataan Reddy et al., (2003) bahwa enzim alfa amilase memiliki $\mathrm{pH}$ optimum pada $\mathrm{pH}$ 4-11. Hasil penelitian ini sesuai dengan hasil Sianturi (2008) yang melaporkan bahwa amilase yang diisolasi dari isolat bakteri PN7 memiliki pH optimum 7 dan Behal et al., (2006) berhasil memperoleh amilase dari Bacillus sp. AB 04 dengan $\mathrm{pH}$ optimum 7-10. 


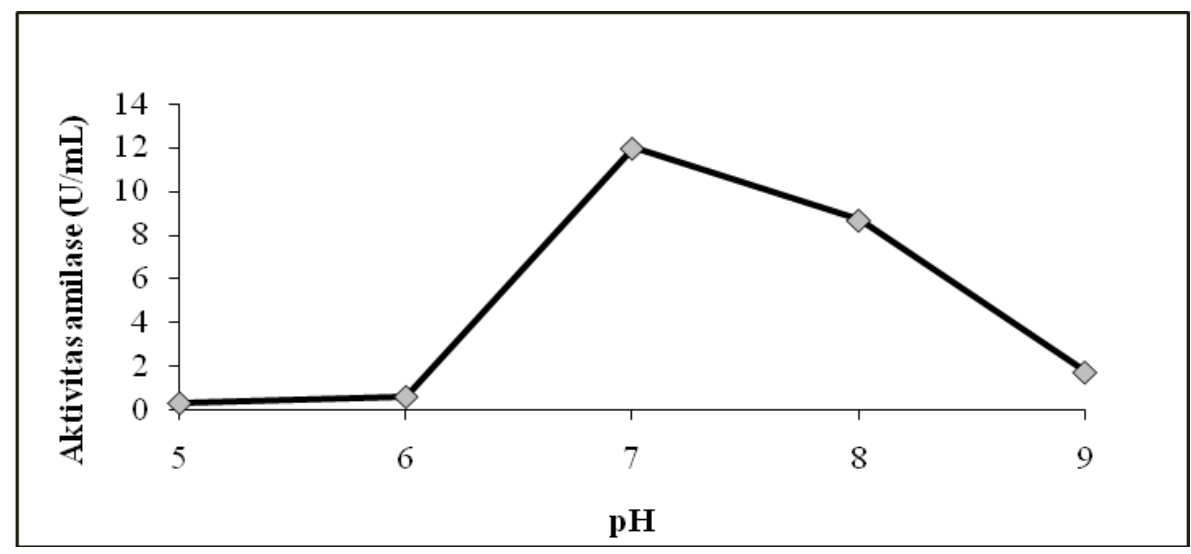

Gambar 2. Kurva pengaruh variasi $\mathrm{pH}$ terhadap aktivitas amilase Azospirillum sp. JG3

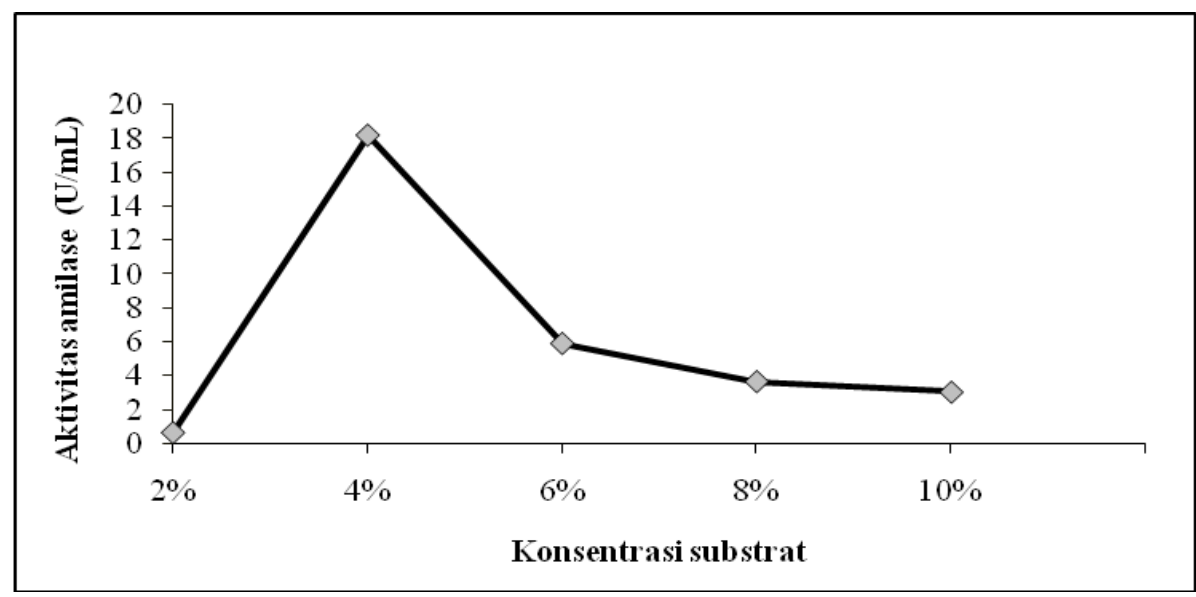

Gambar 3. Kurva pengaruh konsentrasi substrat terhadap aktivitas amilase Azospirillum sp. JG3

\section{Penentuan konsentrasi substrat optimum}

Penentuan konsentrasi substrat optimum digunakan untuk mendapatkan kadar substrat yang tepat untuk menghasilkan aktivitas amilase optimum pada kondisi suhu dan $\mathrm{pH}$ optimum. Konsentrasi substrat optimum akan digunakan untuk produksi dekstrin. Hasil penentuan konsentrasi substrat optimum yang diperoleh dapat dilihat pada Gambar 3.

Berdasarkan hasil penelitian yang terlihat pada Gambar 3 menunjukkan bahwa diperoleh aktivitas amilase tertinggi pada konsentrasi substrat 4\% dengan aktivitas 18,233 U/mL. Analisis statistik menunjukkan konsentrasi $4 \%$ berbeda nyata dengan konsentrasi lainnya. Aktivitas meningkat pada konsentrasi substrat 4\% kemudian menurun pada konsentrasi substrat $6 \%$ sampai $10 \%$. Hal ini terjadi karena konsentrasi substrat sudah melebihi konsentrasi maksimum. Penambahan konsentrasi substrat sampai jumlah tertentu akan mempercepat reaksi enzimatik sampai mencapai optimum. Penambahan konsentrasi substrat melebihi konsentrasi maksimum tidak akan menambah kecepatan reaksi enzimatik, karena sisi aktif enzim telah berikatan semua dengan substrat sehingga penambahan konsentrasi substrat tidak akan mempengaruhi aktivitas enzim (Page, 1997). Penurunan aktivitas enzim setelah konsentrasi $4 \%$ terjadi dimungkinkan karena produk 
menginhibisi atau menjadi inhibitor bagi enzim tersebut dan menyebabkan produksi produk terhambat atau terhenti (Soewoto, 2010).

\section{Pembuatan dekstrin dari pati ubi kayu}

Pembuatan dekstrin dari pati ubi kayu dimulai dengan mengisolasi pati ubi kayu dan membuat larutan pati tersebut. Larutan pati yang diperoleh dinkubasi selama 3 jam pada suhu $95^{\circ} \mathrm{C}$ untuk proses gelatinisasi. Proses ini dimaksudkan untuk mempermudah proses interaksi antara pati dan enzim. Langkah selanjutnya adalah hidrolisis pati ubi kayu menjadi dekstrin dengan katalis amilase FHD $45 \%$ dari Azospirillum sp. JG3. Proses hidrolisis dilakukan pada kondisi optimum amilase FHD $45 \%$ tersebut yaitu suhu $30^{\circ} \mathrm{C}, \mathrm{pH} 7$ dan konsentrasi substrat 4\%. Reaksi hidrolisis berlangsung selama 22 jam hingga diperoleh uji kualitatif dengan larutan iodin yang menghasilkan warna merah kecoklatan. Menurut Winarno (2002), dekstrin telah terbentuk dari hidrolisis pati jika hasil uji iod berwarna merah kecoklatan. Reaksi hidrolisis yang terjadi pada pembuatan dekstrin dan uji iodium yang dilakukan dapat dilihat pada Gambar 4.
Proses hidrolisis pada reaksi diatas memecah pati menjadi amilosa dan amilopektin. Penambahan amilase akan memutus ikatan $\alpha-1,4$ glikosida pada amilosa sehingga menghasilkan dekstrin dan apabila reaksi diteruskan amilase akan memutus ikatan $\alpha-1,4$ glikosida pada dekstrin sehingga dihasilkan maltosa dan glukosa.

Dekstrin yang diperoleh dikeringkan dengan oven pada suhu $50^{\circ} \mathrm{C}$. Dekstrin kering kemudian dikarakterisasi dan hasil yang diperoleh dibandingkan dengan SNI 01-2593 seperti pada Tabel 2.

Berdasarkan hasil penelitian seperti pada Tabel 2, diatas diperoleh rendemen dekstrin dari ubi kayu sebanyak 95,14\%. Rendemen ini lebih tinggi dari rendemen dekstrin umbi talas yaitu 78,56\% (Triyono, 2006). Kadar air yang diperoleh sebanyak 3,41\% menunjukkan bahwa dekstrin yang dihasilkan cukup tahan lama apabila disimpan. Hasil kadar air dari dekstrin yang diperoleh lebih kecil dari kadar air dekstrin pati umbi talas menggunakan enzim komersial diperoleh sebesar 7,69\% (Triyono, 2006) dan masih dibawah standar kadar air maksimal menurut SNI. Menurut Winarno (2002), kadar air dalam makanan ikut menentukan daya tahan bahan tersebut serta mempengaruhi penampakan dan tekstur.

\begin{tabular}{|lcccc|}
\hline & Pati $\longrightarrow$ Dekstrin $\longrightarrow$ Maltosa $\longrightarrow$ Glukosa & & \\
amilase & amilase & & \\
Uji iodium & Biru & Merah Kecoklatan & Kuning \\
\hline
\end{tabular}

Gambar 4. Uji Iodium

(Sumber: Poedjiadi, 1994) 
Tabel 2. Karakterisasi dekstrin dengan katalis amilase FHD 45\% dibanding dengan SNI dekstrin.

\begin{tabular}{|l|l|c|c|}
\hline No & \multicolumn{1}{|c|}{ Karakterisasi } & Dekstrin SNI 01-2593 & Dekstrin Pati Ubi Kayu \\
\hline 1. & Rendemen (\%) & - & 95,14 \\
\hline 2. & Kadar Air (\%) & Maksimal 11 & 3,41 \\
\hline 3. & Kadar Abu (\%) & Maksimal 0,5 & 0,21 \\
\hline 4. & Dekstros Equivalen & Maksimal 20 & 13,3 \\
\hline 5. & Uji Iodium & Ungu sampai kecoklatan & Merah Kecoklatan \\
\hline 6. & Warna & Putih sampai kekuningan & Kekuningan \\
\hline
\end{tabular}

Penentuan kadar abu dilakukan untuk mengetahui kandungan anorganik dari dekstrin. Abu adalah zat anorganik sisa hasil pembakaran suatu bahan organik. Kadar abu yang diperoleh pada penelitian ini sebesar $0,21 \%$. Kadar abu yang diperoleh telah sesuai dengan SNI dekstrin. Kadar abu yang diperoleh masih lebih besar jika dibanding dengan dekstrin yang diperoleh dari pati garut dengan katalis $\mathrm{HCl}$ yaitu sebanyak $0,18 \%$ (Hermianti dan Abbas, 2006).

Pengukuran dextrose ekuivalen (DE) dilakukan untuk mengetahui seberapa jauh pati terhidrolisis menjadi molekul-molekul dengan rantai yang jauh lebih pendek khususnya menjadi dekstrin. Berdasarkan hasil analisis DE dekstrin dari pati ubi kayu menggunakan amilase FHD $45 \%$ diperoleh 13,3. Nilai DE yang diperoleh lebih besar dibandingkan dengan hasil dekstrin sagu yang diperoleh Chafid dan Kusumawardhani (2010) yaitu sebesar 10,23.

\section{KESIMPULAN}

Berdasarkan penelitian yang telah dilakukan dapat disimpulkan bahwa amilase FHD $45 \%$ optimum pada suhu $30^{\circ} \mathrm{C}, \mathrm{pH} 7$ dan konsentrasi substrat $4 \%$. Dekstrin pati ubi kayu dengan katalis amilase FHD 45\% dari Azospirillum sp. JG3 memiliki rendemen 95,14\%, kadar air 3,41\%, kadar abu 0,21\% dan DE 13,3.

\section{UCAPAN TERIMAKASIH}

Penulis mengucapkan terimakasih kepada Jurusan Mipa Fakultas Sains dan Teknik atas bantuan dana penelitian DIPA BLU dan kepada Rias Windiarti atas kerjasamanya selama penelitian.

\section{DAFTAR PUSTAKA}

Alexander, R. \& M.G., Joan, 1993, Basic Biochemical Methods, $2^{\text {nd }}$ Edition, John Willey and Sons, Inc. Publication.

Azmi, J., 1997, Isolasi dan Pemurnian Enzim Amilase dari Aspergillus oryzae yang Ditumbuhkan pada Media Pati Suweg, Jurnal Kimia Andalas, Vol. 3 No.1

Behal, A., J.S.M.K., Sharma, P., Puri \& N., Batra, 2006, Characterization of Alkalin $\alpha$-Amylase From Bacillus sp. AB 04, International Journal of Agriculuture and Biolog, Vol.8 No.1

Bollag, D.M., S.J., Edelstain \& M.D., Rozycki, 1996, Protein Method $1^{\text {st }}$ Edition, John Willey and Sons, Inc., New York.

Chafid, A. \& K., Kusumawardhani, 2010, Modifkasi Tepung Sagu menjadi Maltodekstrin menggunakan Enzim $\alpha$-amilase, Skripsi, Fakultas Teknik UNDIP, Semarang. 
Garret, R.H. \& C.M., Grisham, 1999, Biochemistry, $2^{\text {nd }}$ Edition, Saunders Collage Publishing, USA.

Herminiati, A. \& A., Abbas, 2006, Pemanfaatan Dekstrin dari Pati Garut sebagai Bahan Dasar Makanan bagi Penyandang Autis, Prosiding Seminar Nasional Iptek Solusi Kemandirian Bangsa, 2-3 Agustus 2006, Yogjakarta.

Moreira, F.G., 1999, Production of Amylase by Aspergillus tamari, Revista de Microbiologia, Vol. 30, 157-162.

Ningsih, D.R. \& Zusfahair, 2010, Karakterisasi Enzim Amilase dari Azospirillum sp. JG3, Prosiding Seminar Nasional Kimia UNDIP, Desember 2010, Semarang.

Oedjijono, D., Riyandini, \& I.D.S.A.P., Peramiarti, 2007, Aktivitas Enzimatis Azospirillum pada Substrat Onggok dan Dedak. Laporan Penelitian, Fakultas Biologi Unsoed, Purwokerto.

Page, D.S., 1997, Prinsip-Prinsip Biokimia, Erlangga, Jakarta.

Poedjiadi, A., 1994, Dasar-Dasar Biokimia, UI-Press, Jakarta.

Reddy, N.S., A., Nimmagadda \& K.R., Rao, 2003, An overview of themicrobial $\alpha$-Amylase family, African Journal of Biotechnology, Vol. 2, 645-648.

Rukmana, R. \& Yuniarsih, 2001, Aneka Olahan Ubi Kayu, Penerbit Kanisius, Yogjakarta.

Sadikin, M., 2002, Seri Biokimia: Biokimia Enzim, Widya Medika.

Scopes, R.K., 1987, Protein Purification, Springer Verlag, New York.

Shaw, Jei-Fu, Fu-Pang Lin, \& Su-Chiu Chen, 1995, Purification and
Properties of an Extracellular alfa

Amylase from Thermus sp. Botanical Buletin of Academia Sinica, Vol. 36, 195-200.

Shi, 2000, High Solids, Single Phase Process for Preparing EnzymeConverted Starches, United State Patent No. 6,054,302.

Sianturi, D.C., 2008, Isolasi Bakteri dan Uji Aktivitas Amilase Termofil Kasar dari Sumber Air Panas Panen Sebirubiru Sumatra Utara, Thesis, Universitas Sumatra Utara, Medan.

Soewoto, H., 2001, Biokimia Experimen, Laboratorium Widya Medika, Jakarta.

Standar Nasional Indonesia (SNI), 012593, Pusat Standardisasi Industri Republik Indonesia, Departemen Perindustrian.

Subardjo, B. \& P. Soedigdo, 1992, "Ekstraksi, Isolasi dan Pemurnian Protein dan Bakteri Bongkrek Pseudomonas cocovenenans X128", Majalah Ilmiah-I (XIX):98107.

Sudarmadji, S., 1984, Bahan-Bahan Pemanis, Penerbit Agritech, Yogjakarta.

Thiel, T., 1999, Introduction to Bacteria. In Science in The Real World,Deptement of Biology Univ.of Missouri, St. Louis.

Triyono, A., 2006, Upaya Memanfaatkan Umbi Talas (Colocasia esculeta) sebagai Sumber Bahan Pati pada Pengembangan Teknologi Pembuatan Dekstrin, Prosiding Seminar Nasional Iptek Solusi Kemandirian Bangsa, 2-3 Agustus 2006, Yogyakarta.

Winarno, F.G., 2002, Kimia Pangan dan Gizi, Gramedia Pustaka Utama, Jakarta. 